\title{
Ten Years of Gabor-Domain Optical Coherence Microscopy
}

\author{
Cristina Canavesi ${ }^{1, *(\mathbb{D})}$ and Jannick P. Rolland ${ }^{1,2} \mathbb{D}$ \\ 1 LighTopTech Corp., 150 Lucius Gordon Drive, Suite 201, West Henrietta, NY 14586-9687, USA; \\ rolland@optics.rochester.edu \\ 2 The Institute of Optics, University of Rochester, Rochester, NY 14627, USA \\ * Correspondence: cristina@lightoptech.com
}

Received: 17 April 2019; Accepted: 19 June 2019; Published: 24 June 2019

check for updates

Featured Application: Gabor-domain optical coherence microscopy overcomes the tradeoff between lateral resolution and depth of focus in optical coherence microscopy.

\begin{abstract}
Gabor-domain optical coherence microscopy (GDOCM) is a high-definition imaging technique leveraging principles of low-coherence interferometry, liquid lens technology, high-speed imaging, and precision scanning. GDOCM achieves isotropic $2 \mu \mathrm{m}$ resolution in 3D, effectively breaking the cellular resolution limit of optical coherence tomography (OCT). In the ten years since its introduction, GDOCM has been used for cellular imaging in 3D in a number of clinical applications, including dermatology, oncology and ophthalmology, as well as to characterize materials in industrial applications. Future developments will enhance the structural imaging capability of GDOCM by adding functional modalities, such as fluorescence and elastography, by estimating thicknesses on the nano-scale, and by incorporating machine learning techniques.
\end{abstract}

Keywords: optical coherence tomography; noninvasive imaging; Gabor-domain optical coherence microscopy

\section{Introduction}

Histopathology, the gold standard for diagnosis at the cellular level, suffers from morbidity, cost, and time associated with a biopsy; overcoming these limitations with optical biopsy is the holy grail. The capability to noninvasively image the cellular structures in real-time will revolutionize medicine. The requirements for optical biopsy include cellular resolution $(<5 \mu \mathrm{m})$ in $3 \mathrm{D}, 1 \mathrm{~mm}^{2}$ field of view, and depth of imaging of at least $1 \mathrm{~mm}$ in tissue. Real-time operation is desired.

\section{Strategies for Cellular-Resolution Imaging}

Noninvasive imaging techniques, which include ultrasound, optical coherence tomography (OCT), and confocal microscopy, are routinely used in clinical applications for providing insight on tissue structural morphology. These methods face a tradeoff between spatial resolution and depth of imaging, as depicted in Figure 1, in which the application space is shown in log-scale for the two key parameters of transverse resolution and imaging depth. These two parameters determine what kind of features can be imaged -including cellular and subcellular-and at what depth inside of the tissue. With typical cellular structures having a size of $10-20 \mu \mathrm{m}$, a resolution $<5 \mu \mathrm{m}$ is desired to visualize the cellular morphology. A depth of imaging of $\sim 1 \mathrm{~mm}$ or more is advantageous to track cellular changes in tissue induced by various diseases. 


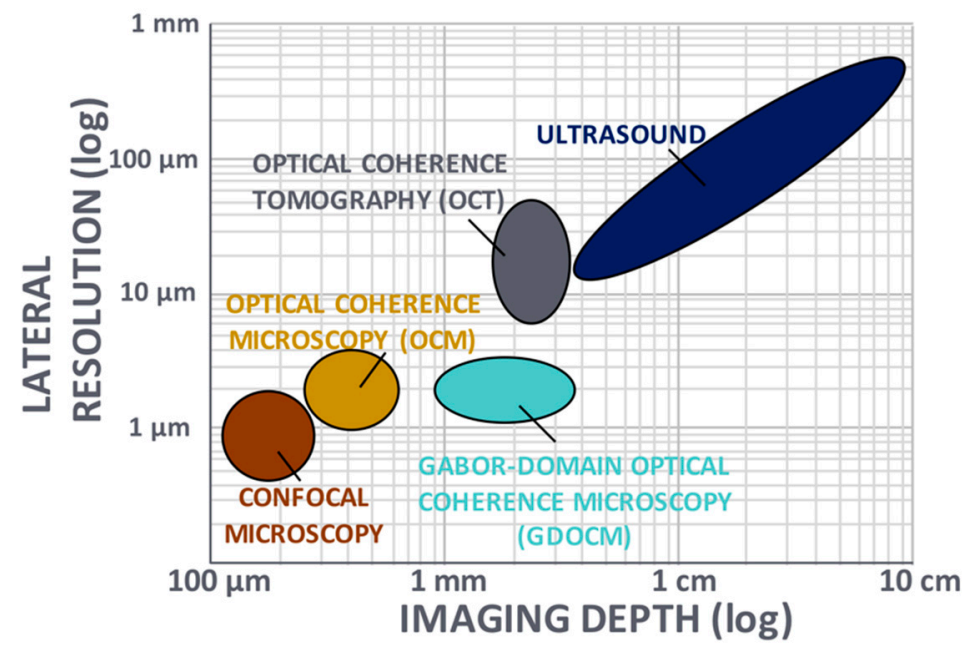

Figure 1. Noninvasive imaging techniques (adapted from [1]). Ultrasound and optical coherence tomography suffer from insufficient lateral resolution for cellular imaging, while confocal microscopy and optical coherence microscopy suffer from limited imaging depth in tissue. Gabor-domain optical coherence microscopy was introduced to overcome the tradeoff between transverse resolution and depth of focus.

OCT is an optical imaging technique based on low-coherence interferometry with an axial resolution on the micrometer-scale and lateral resolution limited to tens of micrometers [2]. OCT produces cross-sectional views of tissue up to a depth of several millimeters. In OCT, transverse and axial resolutions are decoupled. OCT—in particular spectral domain OCT (SD-OCT) —is widely used in ophthalmic and cardiovascular applications [2,3].

Confocal microscopy, with micron or submicron lateral resolution, has depth of imaging limited to tens of micrometers [4]. Optical imaging systems, including OCT and confocal microscopy, face a trade-off between lateral resolution and depth of imaging. To increase the lateral resolution $\Delta x$, the numerical aperture (NA) is increased, resulting in shallower depth of focus (DOF), as illustrated in Figure 2.

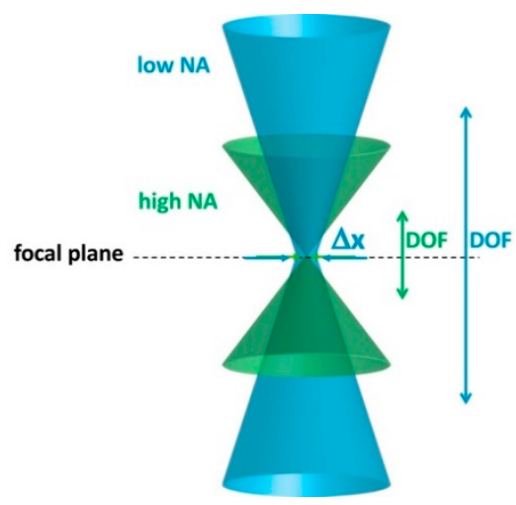

Figure 2. Tradeoff between lateral resolution $(\Delta x)$ and depth of focus (DOF) in an optical imaging system. NA: Numerical aperture.

Optical coherence microscopy (OCM) was introduced as a variant of OCT to achieve micrometer-scale resolution [5]. OCM uses a higher NA objective (i.e., $\sim 0.2)$ than conventional OCT (i.e., $\sim 0.04$ ), and can produce cellular imaging at the expense of a reduction in depth of focus (100-200 $\mu \mathrm{m})$. OCM variants include point-scanning OCM and full-field OCM [6-8]. In full-field OCM, more often referred to as full-field OCT (FF-OCT), en face images are acquired. Computational approaches for extending the depth of focus in OCM have been proposed successfully [9,10]. 
The choice of the light source in OCT and OCM has direct impact on both transverse and axial resolutions, as well as on imaging depth, since transverse resolution is linearly proportional to the central wavelength, axial resolution is inversely proportional to the bandwidth, and longer wavelengths penetrate deeper into tissue. Superluminescent diodes (SLDs) [11] are broadly used in OCT due to availability in the 800,1300, and $1500 \mathrm{~nm}$ spectral bands, relatively large bandwidth (typically 50-100 nm), affordability, and increased brightness (at the expense of bandwidth) over thermal sources [12]. An advantage of fluorescence-based sources, which have been employed in FF-OCT in conjunction with pulsed illumination to reduce motion artifacts, is the smoothness of the spectrum, yet their applicability is limited due to cost and requirement of a high-power laser excitation source [13]. Light-emitting diodes (LEDs), have been described to produce submicron axial resolution in FF-OCT with spatial resolution and sensitivity equivalent to those obtained with halogen sources [14]. Supercontinuum sources offer ultrawide bandwidths (more than $1000 \mathrm{~nm}$ ) and brightness an order of magnitude greater than SLDs, but are still more expensive than SLDs [15]. Yet, they provide superior precision in a thickness estimation task $[16,17]$. Advances in swept sources have led OCT to achieve multi-MHz acquisition speeds [18], while at the same time they often suffer from jitter that may cause significant uncertainty in a class thickness estimation task [16]. To date, visible light OCT mainly employs spatially coherent light sources, however broadband spatially incoherent light sources have been demonstrated successfully [19].

\section{Gabor-Domain Optical Coherence Microscopy}

Gabor-domain optical coherence microscopy (GDOCM) is a high transverse resolution variant of spectral domain optical coherence tomography (SD-OCT) [20]. A schematic of the GDOCM system is shown in Figure 3.

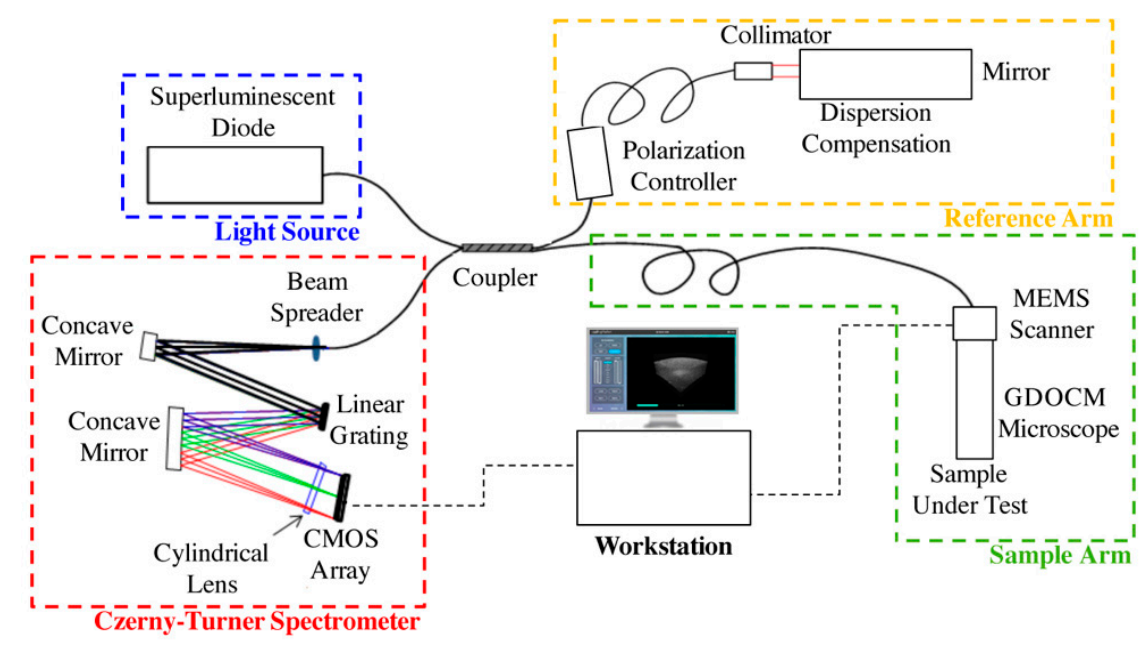

Figure 3. Schematic of a Gabor-domain optical coherence microscopy (GDOCM) microscope consisting of a fiber-based Michelson interferometer. CMOS: Complementary metal oxide semiconductor; MEMS: Microelectromechanical systems.

In GDOCM, the choice of wavelength range in the near infrared was made prioritizing lateral resolution over imaging depth and penetration into tissue. The light source is a superluminescent diode with a center wavelength of $840 \mathrm{~nm}$ and $100 \mathrm{~nm}$ bandwidth, yielding axial resolution of $3.1 \mu \mathrm{m}$ in air and $2 \mu \mathrm{m}$ in tissue (at a refractive index of 1.3). A 50:50 fiber coupler is used for the interferometer. The reference arm performs optical path length matching and dispersion compensation by incorporating a dispersive element [21]. Polarization controllers are used to maximize fringe interference by matching the polarization of the light in the two arms of the interferometer. Optionally, the dispersion and polarization adjustments can be performed to compensate changes in dispersion and polarization introduced by the sample itself. The spectral interference signal is acquired at a line rate of $80 \mathrm{kHz}$, 
with imaging depth in the sample greater than $2 \mathrm{~mm}$ with a custom Czerny-Turner spectrometer, which includes a reflective dispersive element and a line camera with CMOS (complementary metal oxide semiconductor) sensor. The spectrometer design eliminates coma by incorporating two off-axis spherical mirrors, and a cylindrical lens is used to compensate astigmatism in the beam introduced by the off-axis mirrors [22]. A $2 \mu \mathrm{m}$ transverse resolution is achieved over a field of view of $2 \times 2 \mathrm{~mm}$ in the GDOCM microscope design with a numerical aperture of 0.2 , with experimental depth of focus of $\sim 100 \mu \mathrm{m}$ [23]. A compact dual-axis MEMS (microelectromechanical system) mirror integrated in the microscope is used to scan the beam over the 2D field of view [24]. The microscope can be operated in two modalities, to be selected for the desired application: In contact with the sample (with gel medium to create optical contact between the distal surface of the microscope and the sample), or with a working distance of $15 \mathrm{~mm}$. The contact imaging modality may be more advantageous to maximize signal collection in highly scattering tissues such as skin, while the $15 \mathrm{~mm}$ working distance is preferred for ophthalmic applications, or for imaging areas that are more difficult to reach with a contact probe, such as certain locations on the face. In order to obtain micron-resolution imaging over the entire volume, multiple volumetric images of the sample (termed zones) are acquired, each corresponding to a different focusing depth. A good rule of thumb for the number of zones to be acquired is to consider the ratio between total sample depth and the depth of focus; for example, given the depth of focus of $\sim 100 \mu \mathrm{m}$, for a total sample depth of $600 \mu \mathrm{m}$, six zones are required. A liquid lens integrated in the optical design of the microscope achieves dynamic refocusing with no moving parts over a $2 \mathrm{~mm}$ range [25]. The in-focus portions of each volumetric zone are extracted and merged together to produce a high-definition volume with invariant $2 \mu \mathrm{m}$ resolution, both axially and transversally. The process of combining together the in-focus portions of the zones is referred to as fusing. Fusing can be performed either in the spatial or spectral domains [26,27]. As example of a GDOCM image of a human fingertip acquired with three zones and the corresponding fusing procedure is shown in Figure 4.
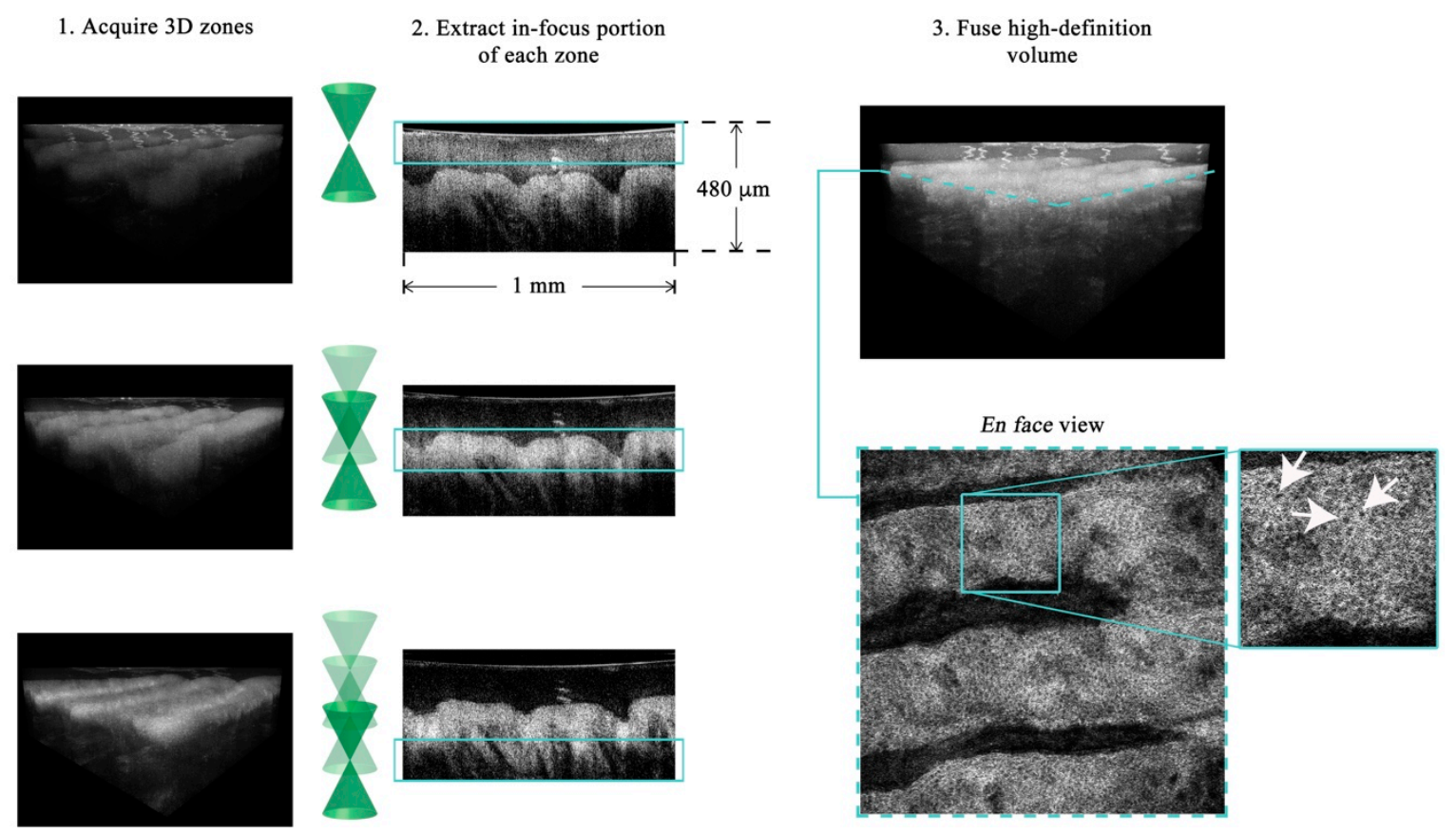

Figure 4. Example of GDOCM image acquisition and fusing of a human fingertip. The field of view is $1 \times 1 \mathrm{~mm}$. After acquiring the desired number of zones (three in this case), the in-focus portions are extracted and fused in a high-definition volumetric image, which achieves cellular resolution throughout the volume. An en face view of the dermoepidermal junction (corresponding to the dashed teal line in the 3D view), with basal cells clearly visible (white arrows), is shown. 
Parallel processing of the acquired data on graphics processing units (GPUs) achieves near real-time visualization of the volumetric images [28].

The 2015 and 2018 implementations of GDOCM are shown in Figure 5. A standalone cart houses the entire GDOCM system. While the first prototype shown in Figure 5a included several elements mounted on a breadboard assembly, the instrument shown in Figure $5 \mathrm{~b}$ was entirely re-engineered with precision mechanics for robust and reliable operation, and incorporates a custom software for semiautomated image acquisition, and 3D image visualization and analysis.

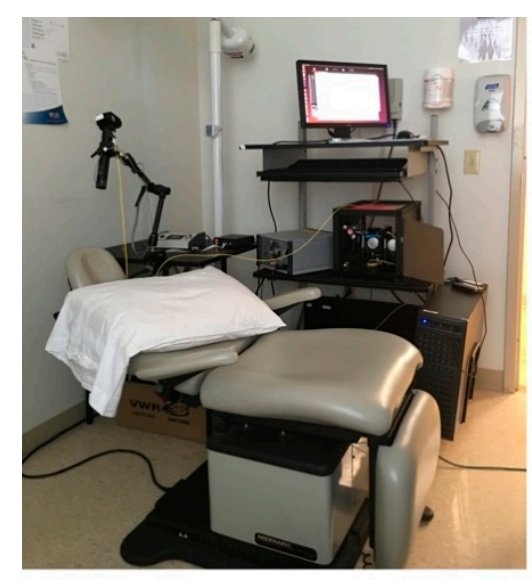

(a)

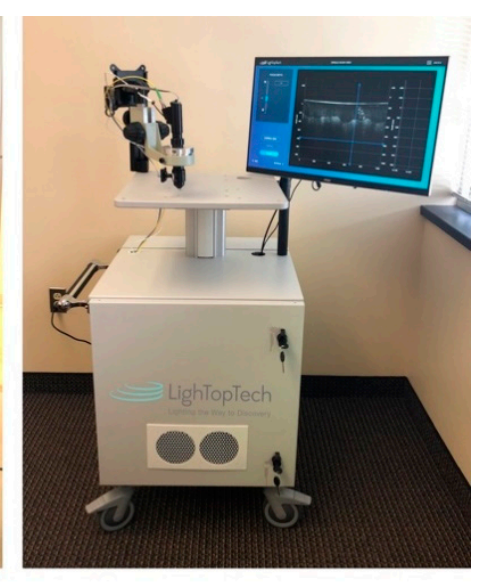

(b)

Figure 5. (a) GDOCM system in use at the University of Rochester Department of Dermatology in its first in vivo study in the fall of 2015; (b) 2018 version of GDOCM (LighTopTech Corp. GDOCM 4D ${ }^{\mathrm{TM}}$ ).

The microscope can be operated either as a handheld or with an articulated arm (see Figure 6, for an example of contact mode with a mechanical arm). The use of a mechanical arm is desired to minimize motion artifacts introduced by operator hand tremor.

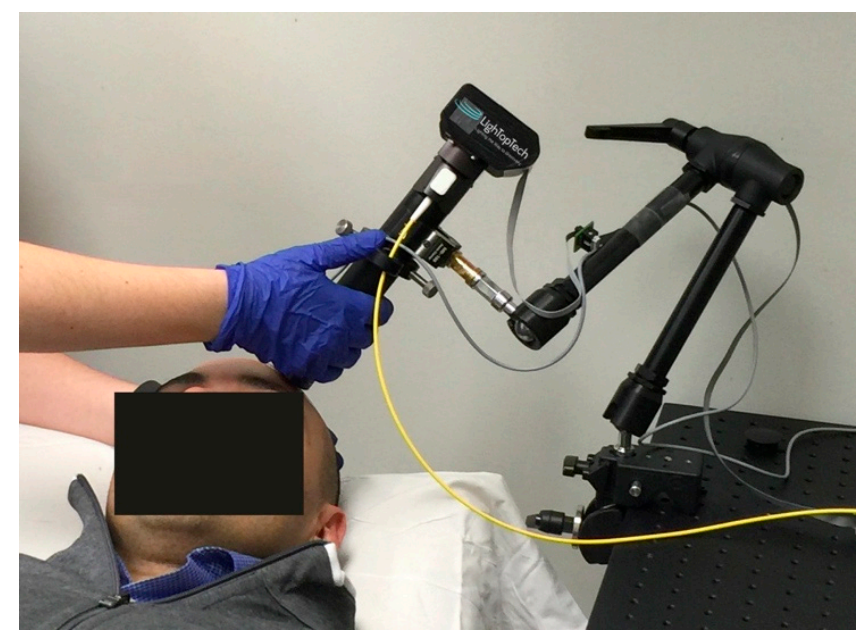

Figure 6. Handheld GDOCM microscope. A mechanical arm can be used to reduce operator hand tremor.

A comparison of the imaging performance of confocal microscopy, spectral domain optical coherence tomography, optical coherence microscopy, full-field optical coherence tomography, and Gabor-domain optical coherence microscopy is reported in Table 1. The performance of the various imaging modalities relates to the chart in Figure 1, with SD-OCT suffering from limited transverse resolution while offering excellent imaging depth of several millimeters, while confocal microscopy, OCM, and FF-OCT achieve subcellular resolution over a limited imaging depth. GDOCM balances these 
parameters to achieve cellular resolution over an imaging depth of $2 \mathrm{~mm}$. SD-OCT, OCM, and GDOCM, being spectral domain OCT systems, have a cross-sectional image orientation, while CM and FF-OCT (time domain OCT) have an en face image orientation. A main limitation of confocal microscopy, unlike OCT, is that the sectioning in depth is set by the NA of the objective lens. Contact operation is typically required with clinical confocal microscopes, however contactless implementations have been proposed. Higher sectioning is obtained with higher NA, yet this occurs at the expense of DOF. Because axial sectioning in OCT is independent of the NA, since it is set by the spectral bandwidth, both higher axial sectioning and larger DOF are possible with OCT. Furthermore, it may be difficult to assess the depth of imaging with confocal, as only en face planes are acquired. SD-OCT acquires depth scans, from which the volume is assembled, and the depth of any en face plane is directly acquired from the depth scan. While the methods that offer higher transverse resolution typically have limited FOV, mosaicking is often used to provide wide FOV imaging, naturally at the expense of acquisition time.

Table 1. Comparison of noninvasive imaging technologies. CM: Confocal microscopy; FF-OCT: Full-field optical coherence tomography; SD-OCT: Spectral domain optical coherence tomography; OCM: Optical coherence microscopy; GDOCM: Gabor-domain optical coherence microscopy.

\begin{tabular}{ccccccc}
\hline Technology & $\begin{array}{c}\text { Axial } \\
\text { Resolution } \\
(\mu \mathrm{m})\end{array}$ & $\begin{array}{c}\text { Transverse } \\
\text { Resolution } \\
(\boldsymbol{\mu m})\end{array}$ & $\begin{array}{c}\text { Imaging } \\
\text { Depth }(\mathbf{m m})\end{array}$ & $\begin{array}{c}\text { Field of View } \\
(\mathbf{m m})\end{array}$ & $\begin{array}{c}\text { Image } \\
\text { Orientation }\end{array}$ & Contact \\
\hline CM [29] & 7.6 & $1-2$ & $<0.1$ & $0.4 \times 0.4$ & En face & Yes \\
SD-OCT [30] & $1-10$ & $10-20$ & 6 & $6-16$ & Cross-sectional & No \\
OCM [31] & 1.5 & 1.5 & $<0.2$ & $0.8 \times 0.8$ & Cross-sectional & Not required \\
FF-OCT [14,32] & $0.7-7.7$ & $1.7-2$ & $<1$ & $0.9-1.3 \times 0.9-1.3$ & En face & Not required \\
GDOCM & 2 & 2.6 & 2.5 & $1.5 \times 1.5$ & Cross-sectional & Not required \\
\hline
\end{tabular}

\section{Applications}

Originally developed for ophthalmic applications to image the posterior segment of the eye [3,33-35] and further enhanced with OCT angiography [36,37], OCT has found successful applications in the anterior segment of the eye [30], as well as in a number of fields, including dermatology [38,39], oncology [40-46] and dentistry [47]; in endoscopic form it has been applied to cardiology [48,49], gastroenterology [50,51], and pulmonology [52-54]. Numerous embodiments of functional OCT [55], including Doppler OCT and polarization-sensitive OCT [56,57], as well as optical coherence elastography [58-64], multimodal fluorescence-OCT [2,65-67] and spectroscopic OCT [68], have been developed to enhance the structural information obtained with OCT with properties related to tissue function.

To date, GDOCM has been used in a number of medical applications, including human skin ex vivo [69,70] and in vivo [71], human corneas ex vivo [72], mouse cornea in vivo, and cervical tissue ex vivo [73], as well as industrial applications [74,75]. When reviewing the images, having access to the $3 \mathrm{D}$ views offers additional insights into tissue morphology; the en face views are useful to visualize cellular structures. Representative images of human skin, cornea, and cervical tissue are shown in Figure 7. The depth cross-sections can be directly related to traditional histology slices, since they are presented in the same orientation. The en face views, which are in the traditional orientation of microscopy, including confocal microscopy, highlight the presence of cellular structures, including endothelial cells (Figure 7b, bottom) and corneal nerves (Figure 7c, bottom). Various diseases that cause disruption of the cellular network, such as basal cell carcinoma (BCC) and cervical dysplasia, can be assessed, such as in Figure 7a,d. Various measurements can be conducted on the 3D GDOCM images to extract relevant parameters, such as quantifying the thicknesses of various sublayers of the tissue, and estimating the cell density [76]. 
Human skin in vivo
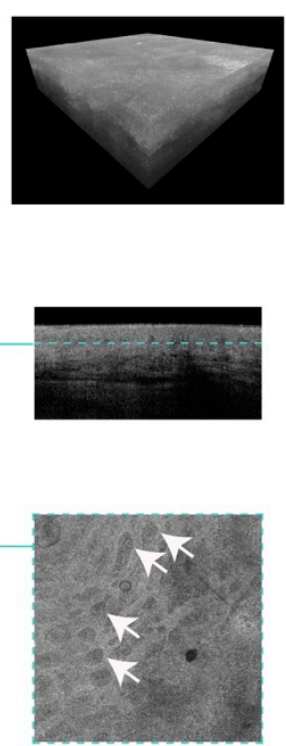

(a)
Human cornea ex vivo
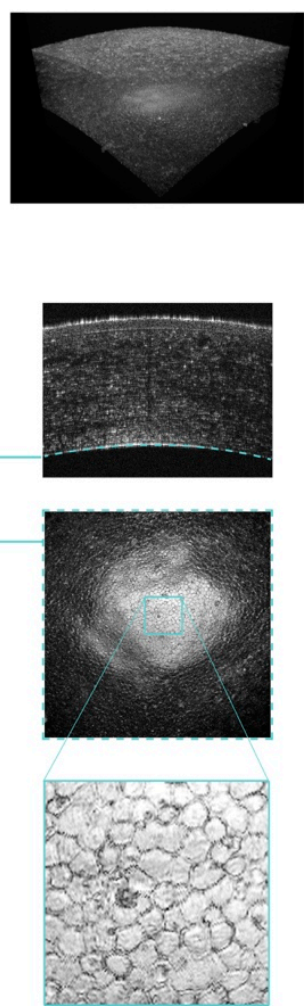

(b)
Mouse cornea in vivo
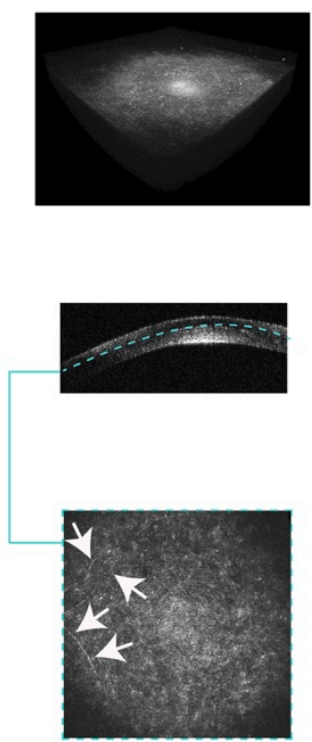

(c)
Cervix ex vivo
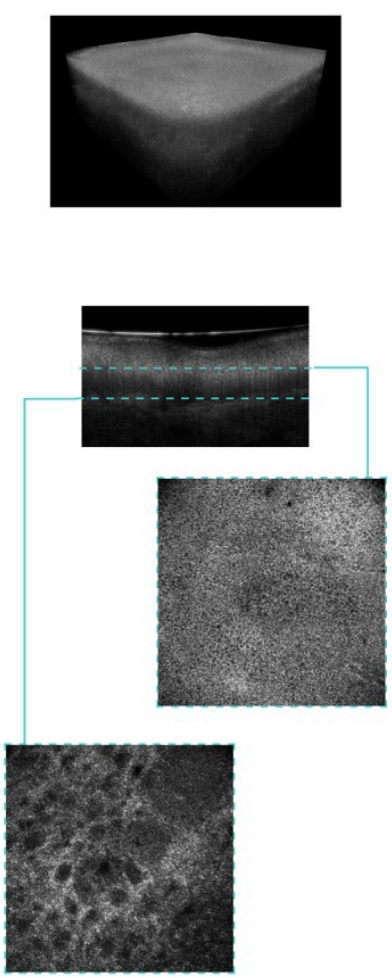

(d)

Figure 7. Representative 3D, cross-sectional, and en face views for different GDOCM applications: (a) In vivo human skin with basal cell carcinoma (BCC), (b) ex vivo human cornea, (c) in vivo mouse cornea, and (d) ex vivo human cervical tissue. The images have a field of view of $1 \times 1 \mathrm{~mm}$. The arrows in the en face view of in vivo human skin indicate the BCC. The en face view of the human cornea shows the endothelium, a single layer of cells lining the posterior surface of the cornea, with the endothelial cells clearly visible. The arrows in the en face view of a mouse cornea acquired in vivo indicate the corneal nerves. In the images of uterine cervix, cervical stroma, basement membrane, and cervical epithelium are visible.

\section{Conclusions}

A number of developments are under course to further enhance the cellular-resolution imaging capabilities of GDOCM. These include applying machine learning to automatically segment features of interest of the image; adding functional capabilities to enhance GDOCM's structural imaging at the microscopic level, such as fluorescence and elastography; and thickness estimation of nano-scale layers.

Funding: This research was funded by the NYSTAR Foundation, the National Science Foundation, grant numbers IIP-1346453 and IIP-1534701, and the National Institutes of Health, grant numbers 1R43EY028827-01 and 1R43EY029906-01.

Conflicts of Interest: The authors are co-founders and President (C.C.) and CTO (J.P.R.) of LighTopTech Corp.

\section{References}

1. Fujimoto, J.G. Optical Coherence Tomography: Introduction. In Handbook of Optical Coherence Tomography; Bouma, B.E., Tearney, G.J., Eds.; Taylor \& Francis: Boca Raton, FL, USA, 2001; ISBN 9781420002508.

2. Drexler, W.; Liu, M.; Kumar, A.; Kamali, T.; Unterhuber, A.; Leitgeb, R.A. Optical coherence tomography today: Speed, contrast, and multimodality. J. Biomed. Opt. 2014, 19, 71412. [CrossRef] [PubMed] 
3. Zysk, A.M.; Nguyen, F.T.; Oldenburg, A.L.; Marks, D.L.; Boppart, S.A. Optical coherence tomography: A review of clinical development from bench to bedside. J. Biomed. Opt. 2007, 12, 051403. [CrossRef] [PubMed]

4. Minsky, M. Microscopy Apparatus. U.S. Patent 3,013,467, 19 December 1961.

5. Aguirre, A.D.; Hsiung, P.; Ko, T.H.; Hartl, I.; Fujimoto, J.G. High-resolution optical coherence microscopy for high-speed, in vivo cellular imaging. Opt. Lett. 2003, 28, 2064-2066. [CrossRef] [PubMed]

6. Dubois, A.; Grieve, K.; Moneron, G.; Lecaque, R.; Vabre, L.; Boccara, C. Ultrahigh-resolution full-field optical coherence tomography. Appl. Opt. 2004, 43, 2874-2883. [CrossRef] [PubMed]

7. Leitgeb, R.A. En face optical coherence tomography: A technology review. Biomed. Opt. Express 2019, 10, 2177-2201. [CrossRef]

8. Thouvenin, O.; Grieve, K.; Xiao, P.; Apelian, C.; Boccara, A.C. En face coherence microscopy. Biomed. Opt. Express 2017, 8, 622-639. [CrossRef]

9. Ralston, T.S.; Marks, D.L.; Carney, P.S.; Boppart, S.A. Interferometric synthetic aperture microscopy. Nat. Phys. 2007, 3, 129-134. [CrossRef]

10. Ahmad, A.; Shemonski, N.D.; Adie, S.G.; Kim, H.-S.; Hwu, W.-M.W.; Carney, P.S.; Boppart, S.A. Real-time in vivo computed optical interferometric tomography. Nat. Photonics 2013, 7, 444-448. [CrossRef]

11. Shidlovski, V.R. Superluminescent diode light sources for OCT. In Optical Coherence Tomography: Technology and Applications, 2nd ed.; Drexler, W., Fujimoto, J.G., Eds.; Springer: Cham, Switzerland, 2015; ISBN 9783319064192.

12. Fercher, A.F.; Hitzenberger, C.K.; Sticker, M.; Moreno-Barriuso, E.; Leitgeb, R.; Drexler, W.; Sattmann, H. Thermal light source technique for optical coherence tomography. Opt. Commun. 2000, 185, 57-64. [CrossRef]

13. Sacchet, D.; Brzezinski, M.; Moreau, J.; Georges, P.; Dubois, A. Motion artifact suppression in full-field optical coherence tomography. Appl. Opt. 2010, 49, 1480-1488. [CrossRef]

14. Ogien, J.; Dubois, A. High-resolution full-field optical coherence microscopy using a broadband light-emitting diode. Opt. Express 2016, 24, 9922-9931. [CrossRef] [PubMed]

15. Froehly, L.; Meteau, J. Supercontinuum sources in optical coherence tomography: A state of the art and the application to scan-free time domain correlation techniques and depth dependant dispersion compensation. Opt. Fiber Technol. 2012, 18, 411-419. [CrossRef]

16. Huang, J.; Yao, J.; Cirucci, N.; Ivanov, T.; Rolland, J.P. Performance analysis of optical coherence tomography in the context of a thickness estimation task Jinxin Huang tomography in the context of a thickness. J. Biomed. Opt. 2015, 20, 121306. [PubMed]

17. Huang, J.; Hindman, H.B.; Rolland, J.P. In vivo thickness dynamics measurement of tear film lipid and aqueous layers with optical coherence tomography and maximum-likelihood estimation. Opt. Lett. 2016, 41, 1981-1984. [CrossRef] [PubMed]

18. Klein, T.; Huber, R. High-speed OCT light sources and systems. Biomed. Opt. Express 2017, 8, 828-859. [CrossRef] [PubMed]

19. Shu, X.; Beckmann, L.; Zhang, H.F. Visible-light optical coherence tomography: A review. J. Biomed. Opt. 2017, 22, 121707. [CrossRef] [PubMed]

20. Rolland, J.P.; Meemon, P.; Murali, S.; Jain, A.; Papp, N.; Thompson, K.P.; Lee, K.-S. Gabor domain optical coherence microscopy. In Proceedings of the 1st Canterbury Workshop on Optical Coherence Tomography and Adaptive Optics, Proceedings of SPIE, Canterbury, UK, 30 December 2008; Podoleanu, A.G., Ed.; Volume 7139, p. 71390F.

21. Lee, K.-S.; Akcay, A.C.; Delemos, T.; Clarkson, E.; Rolland, J.P. Dispersion control with a Fourier-domain optical delay line in a fiber-optic imaging interferometer. Appl. Opt. 2005, 44, 4009-4022. [CrossRef] [PubMed]

22. Lee, K.-S.; Thompson, K.P.; Rolland, J.P. Broadband astigmatism-corrected Czerny-Turner spectrometer. Opt. Express 2010, 18, 23378-23384. [CrossRef]

23. Murali, S.; Meemon, P.; Lee, K.-S.; Kuhn, W.P.; Thompson, K.P.; Rolland, J.P. Assessment of a liquid lens enabled in vivo optical coherence microscope. Appl. Opt. 2010, 49, D145-D156. [CrossRef]

24. Cogliati, A.; Canavesi, C.; Hayes, A.; Tankam, P.; Duma, V.-F.; Santhanam, A.; Thompson, K.P.; Rolland, J.P. MEMS-based handheld scanning probe with pre-shaped input signals for distortion-free images in Gabor-Domain Optical Coherence Microscopy. Opt. Express 2016, 24, 13365-13374. [CrossRef] 
25. Murali, S.; Thompson, K.P.; Rolland, J.P. Three-dimensional adaptive microscopy using embedded liquid lens. Opt. Lett. 2009, 34, 145-147. [CrossRef] [PubMed]

26. Rolland, J.P.; Meemon, P.; Murali, S.; Thompson, K.P.; Lee, K. Gabor-based fusion technique for Optical Coherence Microscopy. Opt. Express 2010, 18, 3632-3642. [CrossRef] [PubMed]

27. Meemon, P.; Widjaja, J.; Rolland, J.P. Spectral fusing Gabor domain optical coherence microscopy. Opt. Lett. 2016, 41, 508-511. [CrossRef] [PubMed]

28. Tankam, P.; Santhanam, A.P.; Lee, K.-S.; Won, J.; Canavesi, C.; Rolland, J.P. Parallelized multi-graphics processing unit framework for high-speed Gabor-domain optical coherence microscopy. J. Biomed. Opt. 2014, 19, 71410. [CrossRef] [PubMed]

29. Zhivov, A.; Stachs, O.; Stave, J.; Guthoff, R.F. In vivo three-dimensional confocal laser scanning microscopy of corneal surface and epithelium. Br. J. Ophthalmol. 2009, 93, 667. [CrossRef] [PubMed]

30. Ang, M.; Baskaran, M.; Werkmeister, R.M.; Chua, J.; Schmidl, D.; Aranha dos Santos, V.; Garhöfer, G.; Mehta, J.S.; Schmetterer, L. Anterior segment optical coherence tomography. Prog. Retin. Eye Res. 2018, 66, 132-156. [CrossRef] [PubMed]

31. Tan, B.; Hosseinaee, Z.; Han, L.; Kralj, O.; Sorbara, L.; Bizheva, K. 250 kHz, 1.5 um resolution SD-OCT for in-vivo cellular imaging of the human cornea. Biomed. Opt. Express 2018, 9, 6569-6583. [CrossRef] [PubMed]

32. Mazlin, V.; Xiao, P.; Dalimier, E.; Grieve, K.; Irsch, K.; Sahel, J.-A.; Fink, M.; Boccara, A.C. In vivo high resolution human corneal imaging using full-field optical coherence tomography. Biomed. Opt. Express 2018, 9,557-568. [CrossRef]

33. Fujimoto, J.; Swanson, E. The development, commercialization, and impact of optical coherence tomography. Investig. Ophthalmol. Vis. Sci. 2016, 57, OCT1-OCT13. [CrossRef]

34. Vakoc, B.J.; Fukumura, D.; Jain, R.K.; Bouma, B.E. Cancer imaging by optical coherence tomography-Preclinical progress and clinical potential. Nat. Rev. Cancer 2012, 12, 363-368. [CrossRef]

35. Drexler, W.; Fujimoto, J.G. State-of-the-art retinal optical coherence tomography. Prog. Retin. Eye Res. 2008, 27, 45-88. [CrossRef] [PubMed]

36. Spaide, R.F.; Fujimoto, J.G.; Waheed, N.K.; Sadda, S.R.; Staurenghi, G. Optical coherence tomography angiography. Prog. Retin. Eye Res. 2018, 64, 1-55. [CrossRef] [PubMed]

37. Kashani, A.H.; Chen, C.L.; Gahm, J.K.; Zheng, F.; Richter, G.M.; Rosenfeld, P.J.; Shi, Y.; Wang, R.K. Optical coherence tomography angiography: A comprehensive review of current methods and clinical applications. Prog. Retin. Eye Res. 2017, 60, 66-100. [CrossRef] [PubMed]

38. Gambichler, T.; Pljakic, A.; Schmitz, L. Recent advances in clinical application of optical coherence tomography of human skin. Clin. Cosmet. Investig. Dermatol. 2015, 8, 345-354. [CrossRef] [PubMed]

39. Olsen, J.; Holmes, J.; Jemec, G.B.E. Advances in optical coherence tomography in dermatology-A review. J. Biomed. Opt. 2018, 23, 040901. [CrossRef] [PubMed]

40. Wilder-Smith, P.; Krasieva, T.; Jung, W.-G.; Zhang, J.; Chen, Z.; Osann, K.; Tromberg, B. Noninvasive imaging of oral premalignancy and malignancy. J. Biomed. Opt. 2005, 10, 051601. [CrossRef] [PubMed]

41. Escobar, P.F.; Rojas-Espaillat, L.; Tisci, S.; Enerson, C.; Brainard, J.; Smith, J.; Tresser, N.J.; Feldchtein, F.I.; Rojas, L.B.; Belinson, J.L. Optical coherence tomography as a diagnostic aid to visual inspection and colposcopy for preinvasive and invasive cancer of the uterine cervix. Int. J. Gynecol. Cancer 2006, 16, 1815-1822. [CrossRef] [PubMed]

42. Gallwas, J.; Jalilova, A.; Ladurner, R.; Kolben, T.M.; Kolben, T.; Ditsch, N.; Homann, C.; Lankenau, E.; Dannecker, C. Detection of cervical intraepithelial neoplasia by using optical coherence tomography in combination with microscopy. J. Biomed. Opt. 2017, 22, 16013. [CrossRef]

43. Assayag, O.; Grieve, K.; Devaux, B.; Harms, F.; Pallud, J.; Chretien, F.; Boccara, C.; Varlet, P. Imaging of non-tumorous and tumorous human brain tissues with full-field optical coherence tomography. NeuroImage Clin. 2013, 2, 549-557. [CrossRef]

44. Nguyen, F.T.; Zysk, A.M.; Chaney, E.J.; Kotynek, J.G.; Oliphant, U.J.; Bellafiore, F.J.; Rowland, K.M.; Johnson, P.A.; Boppart, S.A. Intraoperative evaluation of breast tumor margins with optical coherence tomography. Cancer Res. 2009, 69, 8790-8796. [CrossRef]

45. Betz, C.S.; Volgger, V.; Silverman, S.M.; Rubinstein, M.; Kraft, M.; Arens, C.; Wong, B.J.F. Clinical optical coherence tomography in head \& neck oncology: Overview and outlook. Head Neck Oncol. 2013, 5, 35.

46. Wang, J.; Xu, Y.; Boppart, S.A. Review of optical coherence tomography in oncology. J. Biomed. Opt. 2017, 22, 121711. [CrossRef] [PubMed] 
47. Machoy, M.; Seeliger, J.; Szyszka-Sommerfeld, L.; Koprowski, R.; Gedrange, T.; Woźniak, K. The Use of Optical Coherence Tomography in Dental Diagnostics: A State-of-the-Art Review. J. Healthc. Eng. 2017, 2017. [CrossRef]

48. Fujimoto, J.G.; Schmitt, J.M.; Swanson, E.A.; Jang, I.K. The development of OCT. In Cardiovascular OCT Imaging; Springer: Cham, Switzerland, 2015; ISBN 9783319108018.

49. Bezerra, H.G.; Costa, M.A.; Guagliumi, G.; Rollins, A.M.; Simon, D.I. Intracoronary Optical Coherence Tomography: A Comprehensive Review. Clinical and Research Applications. JACC Cardiovasc. Interv. 2009, 2, 1035-1046. [CrossRef] [PubMed]

50. Tearney, G.J.; Brezinski, M.E.; Bouma, B.E.; Boppart, S.A.; Pitris, C.; Southern, J.F.; Fujimoto, J.G. In vivo endoscopic optical biopsy with optical coherence tomography. Science 1997, 276, 2037-2039. [CrossRef] [PubMed]

51. Tsai, T.-H.; Leggett, C.L.; Trindade, A.J. Optical coherence tomography in gastroenterology: A review and future outlook. J. Biomed. Opt. 2017, 22, 121716. [CrossRef] [PubMed]

52. McLaughlin, R.A.; Yang, X.; Quirk, B.C.; Lorenser, D.; Kirk, R.W.; Noble, P.B.; Sampson, D.D. Static and dynamic imaging of alveoli using optical coherence tomography needle probes. J. Appl. Physiol. 2012, 113, 967-974. [CrossRef]

53. Lorenser, D.; Quirk, B.C.; Auger, M.; Madore, W.-J.; Kirk, R.W.; Godbout, N.; Sampson, D.D.; Boudoux, C.; McLaughlin, R.A. Dual-modality needle probe for combined fluorescence imaging and three-dimensional optical coherence tomography. Opt. Lett. 2013, 38, 266-268. [CrossRef] [PubMed]

54. Hariri, L.P.; Mino-Kenudson, M.; Lanuti, M.; Miller, A.J.; Mark, E.J.; Suter, M.J. Diagnosing lung carcinomas with optical coherence tomography. Ann. Am. Thorac. Soc. 2015, 12, 193-201. [CrossRef]

55. Kim, J.; Brown, W.; Maher, J.R.; Levinson, H.; Wax, A. Functional optical coherence tomography: Principles and progress. Phys. Med. Biol. 2015, 60, R211-R237. [CrossRef]

56. de Boer, J.F.; Hitzenberger, C.K.; Yasuno, Y. Polarization sensitive optical coherence tomography-A review. Biomed. Opt. Express 2017, 8, 1838. [CrossRef]

57. Canavesi, C.; Morichetti, F.; Canciamilla, A.; Persia, F.; Melloni, A. Polarization- and phase-sensitive low-coherence interferometry setup for the characterization of integrated optical components. J. Light. Technol. 2009, 27, 3062-3074. [CrossRef]

58. Zvietcovich, F.; Rolland, J.P.; Yao, J.; Meemon, P.; Parker, K.J. Comparative study of shear wave-based elastography techniques in optical coherence tomography. J. Biomed. Opt. 2017, 22, 35010. [CrossRef] [PubMed]

59. Meemon, P.; Yao, J.; Chu, Y.-J.; Zvietcovich, F.; Parker, K.J.; Rolland, J.P. Crawling wave optical coherence elastography. Opt. Lett. 2016, 41, 847-850. [CrossRef] [PubMed]

60. Sun, C.; Standish, B.; Yang, V.X.D. Optical coherence elastography: Current status and future applications. J. Biomed. Opt. 2011, 16, 043001. [CrossRef] [PubMed]

61. Wang, S.; Larin, K.V. Optical coherence elastography for tissue characterization: A review. J. Biophotonics 2015, 8, 279-302. [CrossRef]

62. Kennedy, B.F.; Kennedy, K.M.; Sampson, D.D. A review of optical coherence elastography: Fundamentals, techniques and prospects. IEEE J. Sel. Top. Quantum Electron. 2014, 20, 1-17. [CrossRef]

63. Rolland, J.P.; Zvietcovich, F.; Ge, G.; Parker, K.J. Perspectives and advances in optical elastography. In Proceedings of the Optical Elastography and Tissue Biomechanics VI, San Francisco, CA, USA, 2-7 February 2019; Volume 10880, p. 108800G.

64. Mulligan, J.A.; Untracht, G.R.; Chandrasekaran, S.N.; Brown, C.N.; Adie, S.G. Emerging Approaches for High-Resolution Imaging of Tissue Biomechanics with Optical Coherence Elastography. IEEE J. Sel. Top. Quantum Electron. 2016, 22, 6800520. [CrossRef]

65. Auksorius, E.; Bromberg, Y.; Motiejūnaitè, R.; Pieretti, A.; Liu, L.; Coron, E.; Aranda, J.; Goldstein, A.M.; Bouma, B.E.; Kazlauskas, A.; et al. Dual-modality fluorescence and full-field optical coherence microscopy for biomedical imaging applications. Biomed. Opt. Express 2012, 3, 661-666. [CrossRef]

66. Makhlouf, H.; Perronet, K.; Dupuis, G.; Lévêque-Fort, S.; Dubois, A. Simultaneous optically sectioned fluorescence and optical coherence microscopy with full-field illumination. Opt. Lett. 2012, 37, 1613-1615. [CrossRef]

67. Thouvenin, O.; Fink, M.; Boccara, C. Dynamic multimodal full-field optical coherence tomography and fluorescence structured illumination microscopy. J. Biomed. Opt. 2017, 22, 26004. [CrossRef] [PubMed] 
68. Nam, H.S.; Yoo, H. Spectroscopic optical coherence tomography: A review of concepts and biomedical applications. Appl. Spectrosc. Rev. 2018, 53, 91-111. [CrossRef]

69. Lee, K.-S.; Zhao, H.; Ibrahim, S.F.; Meemon, N.; Khoudeir, L.; Rolland, J.P. Three-dimensional imaging of normal skin and nonmelanoma skin cancer with cellular resolution using Gabor domain optical coherence microscopy. J. Biomed. Opt. 2012, 17, 126006. [CrossRef] [PubMed]

70. Rolland, J.P.; Lee, K.S.; Meemon, P.; Ibrahim, S.F. Gabor Domain Optical Coherence Microscopy of Human Skin. In Advances in Dermatological Sciences; The Royal Society of Chemistry: London, UK, 2014; pp. 37-52. ISBN 978-1-84973-398-4.

71. Tankam, P.; Soh, J.; Canavesi, C.; Lanis, M.; Hayes, A.; Cogliati, A.; Rolland, J.P.; Ibrahim, S.F. Gabor-Domain Optical Coherence Tomography to Aid in Mohs Resection of Basal Cell Carcinoma. J. Am. Acad. Dermatol. 2019, 80, 1766-1769. [CrossRef] [PubMed]

72. Tankam, P.; He, Z.; Thuret, G.; Hindman, H.B.; Canavesi, C.; Coyoc Escudero, J.; Lepine, T.; Gain, P.; Rolland, J.P. Capabilities of Gabor-domain Optical Coherence Microscopy for the Assessment of Corneal Disease. J. Biomed. Opt. 2019, 24, 046002.

73. Canavesi, C.; O'Connell, R.; Pazcos, T.; Cogliati, A.; Hayes, A.; Bonham, A.; Rolland, J.P. Gabor-domain optical coherence microscopy for optical biopsy, image-guided surgery, and intraoperative imaging. Int. J. CARS (Computer Assisted Radiology and Surgery) 2019, 14 (Suppl. 1), S18-S19.

74. Canavesi, C.; Cogliati, A.; Hayes, A.; Santhanam, A.P.; Tankam, P.; Rolland, J.P. Gabor-domain optical coherence microscopy with integrated dual-axis MEMS scanner for fast 3D imaging and metrology. In Proceedings of the SPIE-The International Society for Optical Engineering, New York, NY, USA, 11 October 2015; Volume 9633, p. 96330 .

75. Tankam, P.; Won, J.; Canavesi, C.; Cox, I.; Rolland, J.P. Optical Assessment of Soft Contact Lens Edge-Thickness. Optom. Vis. Sci. 2016, 93, 987-996. [CrossRef]

76. Canavesi, C.; Cogliati, A.; Yoon, C.; Mietus, A.; Qi, Y.; Stone, J.J.; Hindman, H.B.; Rolland, J.P. 3D cellular imaging of the cornea with Gabor-domain optical coherence microscopy. In Proceedings of the SPIE 10867, Optical Coherence Tomography and Coherence Domain Optical Methods in Biomedicine XXIII, San Francisco, CA, USA, 2-7 February 2019; p. 108670F.

(C) 2019 by the authors. Licensee MDPI, Basel, Switzerland. This article is an open access article distributed under the terms and conditions of the Creative Commons Attribution (CC BY) license (http://creativecommons.org/licenses/by/4.0/). 